\title{
Water Status in the Syrian Water Basins
}

\author{
Khaldoon A. Mourad ${ }^{1}$, Ronny Berndtsson ${ }^{2}$ \\ ${ }^{1}$ Department of Water Resources Engineering, Lund University, Lund, Sweden; ${ }^{2}$ Center for Middle Eastern Studies and Department \\ of Water Resources Engineering, Lund University, Lund, Sweden. \\ Email: Khaldoon.Mourad@tvrl.lth.se
}

Received August $2^{\text {nd }}, 2011$; revised October $13^{\text {th }}, 2011$; accepted December $5^{\text {th }}, 2011$

\begin{abstract}
Syrian water resources face economic and physical water scarcity. This together with a large population and development increase and the climate change may lead to increasing risks for international controversies and disputes in the coming decades. According to FAO, the available water resource per capita AWPC is going to be half by 2025. Depending on its seven water basins, this paper analyses water demand and supply in the Syria with their projections till 2050. The paper shows that two of the seven Syrian basins need a specific concern as they face water scarcity problem. However, two basins have extra water. Therefore, the paper focuses on the need for a sustainable water management, which takes all nonconventional water resources into account to contribute in the Syrian water balance such as rainwater harvesting and wastewater reuse.
\end{abstract}

Keywords: Renewable Water; Middle East; Sanitation; Water Harvesting

\section{Introduction}

Available water in a specific country is defined as the surface and groundwater resources volumes that are renewed each year. Annual available water per capita in Syria will decrease from $2684 \mathrm{~m}^{3}$ in 1970 to $620 \mathrm{~m}^{3}$ in 2025 [1].

Accessible water, on the other hand, is the renewable water that can be accessed and used to a reasonable cost. Good water resources management and by increasing the existing unconventional water resources (e.g., rainwater harvesting, re-use of treated sewage water, improving efficiency in agriculture) play a vital role in increasing the accessible water in a catchment. Decreasing the difference between the available and the accessible water, in a country, reflects the real development in water practices, management, and sanitation.

Water balance of a water basin refers to the balance between the input of water from precipitation, surface \& groundwater flow and the output of water by evaporation, water uses, and stream flow (ground and surface water; $[2,3])$. However, errors and uncertainties can be included due to the difference between unaccounted inputs and outputs, variation in variables, and over-simplification using models [4].

\section{Background and Study Area}

\subsection{Water Resources}

Syria has about 21 million inhabitants distributed in fou- rteen governorates with a total area of about $185,180 \mathrm{~km}^{2}$. Syria can also be divided into seven water basins: Barada \& Awaj, Al-Yarmouk, Orontes, Dajleh \& Khabour, Euphrates \& Aleppo, Desert, and the Coastal Basin "Figure 1", each of which has its own geological, meteorological, hydrological, and demographical characteristics [5]. "Table 1" presents population; area and average precipitation of each water basin.

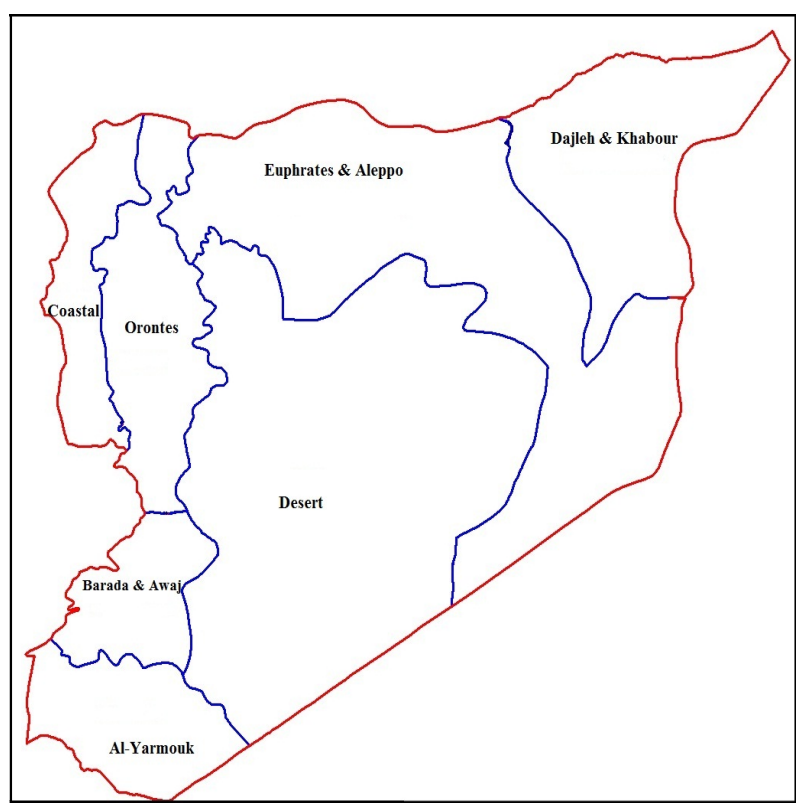

Figure 1. The Syrian water basins. 
Table 1. Characteristics of the Syrian water basins.

\begin{tabular}{cccc}
\hline Water basin & Population & Area $^{\mathrm{a}}(\mathrm{Ha})$ & $\begin{array}{c}\text { Precipitation } \\
(\mathrm{mm})\end{array}$ \\
\hline Barada \& Awaj & $5,700,000$ & 8630 & 275 \\
Al-Yarmouk & $1,404,000$ & 5764 & 318 \\
Orontes & $3,830,000$ & 18,362 & 415 \\
Dajleh \& Khabour & $1,340,000$ & 21,129 & 279 \\
Euphrates \& Aleppo & $5,930,000$ & 51,238 & 217 \\
Desert & 369,000 & 70,786 & 141 \\
Coastal & $1,780,000$ & 5049 & 1147 \\
\hline
\end{tabular}

a. area inside Syrian (excluding the occupied lands).

The annual rainfall in Syria, which occurs from December to March, decreases from about $900 \mathrm{~mm}$ at the coast to about $60 \mathrm{~mm}$ in the eastern part of Syria with an average precipitation about 46000 MCM (Millions $\mathrm{m}^{3}$ ) [6, 7]. Many cities and rural areas have no wastewater treatment plants and some farmers use wastewater in irrigation, which has affected the surface and groundwater quality by increasing nitrate concentrations [8].

The most important water resources in Syria are shared with other countries such as Euphrates, Tigris and Orontes rivers, which have many treaties with Lebanon, Jordan, Iraq, and Turkey to ease managing shared water resources in the region [9].

\subsection{Water Demand}

Depending on its demand sectors, agriculture consumes about $90 \%$ of the Syrian water, which indicates to a real need for further development in irrigation techniques. The total agricultural, domestic and industrial demands were in 2010 about 15,400, 1214, and 648 MCM. Cereal and dry legumes occupy more than $55 \%$ of the total cultivated lands.

\subsection{Water Sector Constraints}

Many constrains are facing water use in Syria. These include physical, economic, technical, and institutional. Below a summary of these are given.

1) Physical constrains: Large seasonal difference in rainfall requiring large storage capacity. About $60 \%$ of the country receives less than $250 \mathrm{~mm} /$ year.

2) Economic constraints: Most water resources projects depend on external funds, which are coordinated by external consultants. This makes projects subject to vulnerability due to weak coordination and cooperation between different stakeholders. Corruption is another factor that tends to weaken the project implementation and local participation.

3) Environmental constraints: The limited number of wastewater treatment plants, operation problems and lack of public awareness has created many environmental problems such as surface and groundwater pollution using untreated wastewater for irrigation, and damaging of treated effluent canals. Moreover, the absence of storm water drains in big cities, especially Damascus, has a negative effect on operation and maintenance of treatment plants.

4) Technical constraints: High water losses, lack of wastewater treatment plants, groundwater contamination due to high nutrient concentration in the treated wastewater and slow implementation of modern irrigation and water-saving technology. The losses in drinking water system for example, are around $25 \%$.

5) Institutional constraints: Many ministries are involved parts of the water sector in Syria. The Ministry of Irrigation (MoI) is responsible for monitoring, management, and development of surface and groundwater resources. The Ministry of Agriculture and Agrarian Reform (MAAR) is responsible for developing irrigation practices in agricultural areas and reusing treated wastewater. The Ministry of Housing and Construction (MoHC) is responsible for drinking water supply and treatment. The Ministry of State for Environmental Affairs is responsible for water protection. Each ministry has its own directorate in the governorates and many ministries include water management in their annual plans. However, overlapping and lack of cooperation is negatively affecting efficient water resources planning and management.

In view of the above, the objective of this paper was to evaluate the water needs and supply in the different Syrian water basins in order to achieve future sustainability. Projections were made up to 2030 and 2050.

\section{Material and Methods}

Available water resources and water demands for each water basin in Syria were estimated using all publically available data from the Ministry of Irrigation (MoI), Central Bureau of Statistics in Syria (CBS), Ministry of Housing and construction (MOHC), and Ministry of Agriculture and Agrarian Reform (MAAR). The future estimated projections depend on the available data.

\subsection{Water Demand Estimation}

"Table 2" shows the actual domestic, industrial, and agricultural water needs in 2008 for the seven water basins according to MoHC and MoI.

Table 2. Water needs.

\begin{tabular}{cccc}
\hline \multirow{2}{*}{ Water basin } & \multicolumn{3}{c}{ Annual water demand (MCM) } \\
\cline { 2 - 4 } & Agriculture & Domestic & Industry \\
\hline Barada \& Awaj & 675 & 340 & 33 \\
Al-Yarmouk & 205 & 118 & 32 \\
Orontes & 2195 & 298 & 235 \\
Dajleh \& Khabour & 4669 & 126 & 11 \\
Euphrates \& Aleppo & 7003 & 526 & 153 \\
Desert & 118 & 42 & 10 \\
Coastal & 530 & 126 & 45 \\
\hline
\end{tabular}




\subsubsection{Agricultural Demand:}

For agricultural demand we assumed that due to water shortage, cultivated land will be constant and the implementation of modern irrigation practices will annually save about $0.5 \%$ of the consumed water.

\subsubsection{Industrial Demand:}

For the industrial sector, the number of industrial projects is increasing every year. According to CBS the annual increase between 1970-2010 was about $1.7 \%$. Therefore we can assume that the annual industrial demand is to increase by $2 \%$.

\subsubsection{Domestic Demand:}

According to Tables $\mathbf{1}$ and 2, we can estimate the daily per capita domestic needs in "Figure 2".

Moreover, According to CBS, the average population increase, all over Syria, decreased from 3\% for 1960-1970 to $2.2 \%$ for $2000-2010$. However the populations increase is different from basins to basin ("Figure 3"). For the future domestic demand projections, we assume, due to the expected improvement in the drinking water systems, that the domestic consumption will be reduced by $10 \%$ by 2030 and another $5 \%$ by 2050 .

\subsection{Annual Renewable Water Resources}

The annual renewable water resources in a basin are the summation of the net surface water flow, the net groundwater flow, and the reclaimed water. The total surface water SW, groundwater GW and reclaimed water RW (agricultural, domestic, and industrial) for the Syrian water basins are presented in "Table 3".

According to MoI, the reclaimed water in 2008 was about 2306, 671, and 407 MCM in agriculture, domestic, and industrial sectors, respectively. This corresponds to about $15 \%, 55 \%$, and $65 \%$ of the totally consumed water in agriculture, domestic, and industrial sector, respectively. In the national development plan, MoHC has announced the construction of more than 20 wastewater treatment plants within the next 20 years. According to this, domestic and industrial wastewaters will be treated up to $85 \%$ by volume in 2040 . This gives an average annual increase of treated domestic and industrial wastewater of about $1 \%$ and $0.5 \%$, respectively.

\subsection{Climate Change Effect}

Climate change will have severe impacts on regional water stress [10]. The Middle East is likely to face a decrease in precipitation amount by $20 \%-25 \%$, which will reduce the runoff with about 23\%, and Euphrates River flow may be reduced by $29 \%$ - 73\% [11]. Moreover, Middle East average temperature may increase by about $2.5^{\circ} \mathrm{C}$ to 2050 , which will affect evaporated water amounts [11]. Hence,

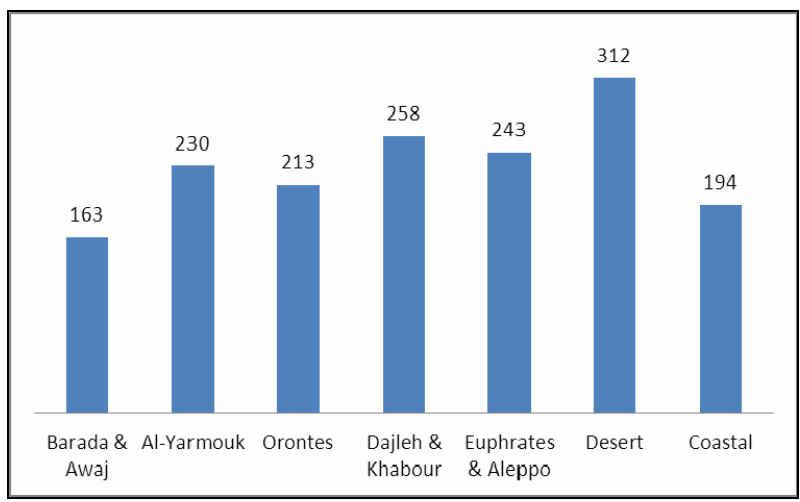

Figure 2 . The daily water consumption per capita (L).

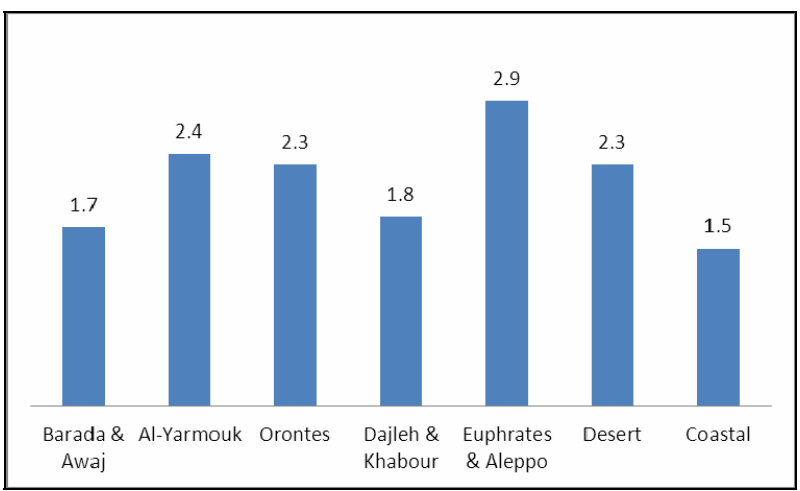

Figure 3. Annual population increases (\%).

Table 3. Annual renewable water resources.

\begin{tabular}{cccccc}
\hline & \multicolumn{4}{c}{ Annual water resources (MCM) } \\
\cline { 2 - 6 } Water basin & SW & GW & \multicolumn{3}{c}{ RW } \\
& & & Ag. & Do. & In. \\
\hline Barada \& Awaj & 37 & 470 & 99 & 204 & 26 \\
Al-Yarmouk & 24 & 170 & 9 & 47 & 26 \\
Orontes & 662 & 891 & 53 & 32 & 188 \\
Dajleh \& Khabour & 152 & 2000 & 467 & 101 & 9 \\
Euphrates \& Aleppo & 7134 & 645 & 1410 & 210 & 122 \\
Desert & 21 & 150 & 0 & 3 & 0 \\
Coastal & 715 & 485 & 53 & 32 & 36 \\
\hline
\end{tabular}

we assumed an annual reduction in surface and groundwater resources by about $0.25 \%$ and an annual increase in evaporation rate by about $0.25 \%$ up to 2050 .

\section{Results and Discussion}

\subsection{Water Demand and Resources Projections}

According to the above, without building any scenario, population, agricultural demand, industrial demand, and domestic demand of the Syrian water basins for 2030 and 2050 are presented in Table $\mathbf{4}$. While Table 5 presents water demands and resources projections in 2030 and 2050. 
Table 4. Water demands projections.

\begin{tabular}{ccccccccc}
\hline \multirow{2}{*}{ Water basin } & \multicolumn{4}{c}{2030} \\
\cline { 2 - 8 } & \multirow{3}{*}{ Population } & \multicolumn{3}{c}{ Water demand (MCM) } & Population & \multicolumn{3}{c}{ Water demand (MCM) } \\
& & Domestic & Agriculture & Industry & & Domestic & Agriculture & Industry \\
\hline Barada \& Awaj & 8029476 & 430 & 631 & 49 & 10991550 & 559 & 625 & 71 \\
Al-Yarmouk & 2242356 & 169 & 192 & 48 & 3447847 & 247 & 190 & 69 \\
Orontes & 6011108 & 421 & 2053 & 350 & 9094206 & 605 & 2033 & 504 \\
Dajleh \& Khabour & 1922739 & 163 & 4367 & 16 & 2677222 & 216 & 4323 & 24 \\
Euphrates \& Aleppo & 10140774 & 809 & 6550 & 228 & 16614645 & 1260 & 6485 & 328 \\
Desert & 569028 & 58 & 110 & 15 & 846941 & 82 & 109 & 21 \\
Coastal & 2325178 & 148 & 496 & 67 & 2969020 & 180 & 491 & 96 \\
\hline
\end{tabular}

Table 5. Water resources projections.

\begin{tabular}{|c|c|c|c|c|c|c|c|c|c|c|c|}
\hline \multirow{3}{*}{ Water basin } & \multicolumn{5}{|c|}{2030} & \multirow{3}{*}{ Water basin } & \multicolumn{5}{|c|}{2050} \\
\hline & \multirow{2}{*}{$\begin{array}{c}\text { Surface } \\
\text { water }\end{array}$} & \multirow{2}{*}{$\begin{array}{l}\text { Ground } \\
\text { water }\end{array}$} & \multicolumn{3}{|c|}{ Reclaimed water } & & \multirow{2}{*}{$\begin{array}{l}\text { Surface } \\
\text { water }\end{array}$} & \multirow{2}{*}{$\begin{array}{l}\text { Ground } \\
\text { water }\end{array}$} & \multicolumn{3}{|c|}{ Reclaimed water } \\
\hline & & & Do. & Ag. & In. & & & & Do. & Ag. & In. \\
\hline Barada \& Awaj & 35 & 447 & 259 & 93 & 39 & Barada \& Awaj & 33 & 425 & 336 & 92 & 56 \\
\hline Al-Yarmouk & 23 & 162 & 68 & 8 & 39 & Al-Yarmouk & 22 & 154 & 99 & 8 & 56 \\
\hline Orontes & 629 & 847 & 45 & 50 & 280 & Orontes & 598 & 805 & 65 & 49 & 403 \\
\hline Dajleh \& Khabour & 144 & 1901 & 130 & 437 & 13 & Dajleh \& Khabour & 137 & 1807 & 173 & 432 & 19 \\
\hline Euphrates \& Aleppo & 6782 & 613 & 323 & 1319 & 182 & Euphrates \& Aleppo & 6447 & 583 & 503 & 1306 & 261 \\
\hline Desert & 20 & 143 & 4 & 0 & 0 & Desert & 19 & 136 & 6 & 0 & 0 \\
\hline Coastal & 680 & 461 & 38 & 50 & 54 & Coastal & 646 & 438 & 46 & 49 & 77 \\
\hline
\end{tabular}

\subsection{Water Balance}

According to Tables $\mathbf{4}$ and $\mathbf{5}$ water balance calculations showed that five of the seven water basins are in a water scarce condition till 2050. However, Coastal and Euphrates \& Aleppo Basins will keep in the decreasing positive track (Figure 4). Therefore, a vital action is needed to solve these water shortages.

\subsection{Scenarios for a Better future}

\subsubsection{Water Transfer between Basins.}

In this scenario we chose two neighboring basins, one with a water shortage problem and the other with more water availability. The following two examples were proposed.

a) The Orontes and Coastal basins.

Pumping 600 MCM per year of water from the Coastal basin to the Orontes basin, will decrease water shortage in the Orontes basin. However, this also means that the Coastal basin needs extra water according to "Figure 5".

b) The Desert, Dajleh \& Khabour and Euphrates \& Aleppo basins.

Euphrates \& Aleppo basin is rich with water. However, its neighbors Desert and Dajleh \& Khabour basins have water shortage problems. If we keep the Euphrates \& Aleppo and Desert basins balanced we can pump 1960, 1614, 1308, and $974 \mathrm{MCM}$ in 2020, 2030, 2040, and 2050, respectively to Dajleh \& Khabour basin. Yet this is not enough for this basin "Figure 6".

\subsubsection{Regional Cooperation.}

Regional cooperation is needed to solve Dajleh \& Khabour, Barada \& Awaj, and Al-Yarmouk basins. For Dajleh \& Khabour basin, an annual amount of 500 MCM of water from Tigris river with some water saving and modern irrigation can keep the basin balanced. Al-Yarmouk and Barada \& Awaj basins can be balanced by the Syrian water in the occupied Golan heights.

\subsubsection{Technical Scenario.}

We assumed an optimistic scenario that the water consumption per capita will be 125 liters in 2030, due to the improvements in the water supply networks and the implementation of water saving devices, which gives 1.9, 5.25, 4.4, 6.65, 5.9, 9.35, and 3.45 Lpcd as an annual decrease in the domestic water consumption till 2030 in the Barada \& Awaj, Al-Yarmouk, Orontes, Dajleh \& Khabour, Euphrates \& Aleppo, Desert, and the Coastal basin, respectively. Moreover, we assumed that all domestic and industrial wastewater will be reused ( $90 \%$ of the demand) and that rainwater-harvesting techniques will save another $1.5 \%$ of the total rainfall in each basin by 2030 . The results from this scenario are presented in "Figure 7".

Figure 7 shows that this scenario can balance more basins. However, Dajleh \& Khabour and Orontes basins still have water shortage status.

\section{Conclusions}

Syria is considered a water-scarce country as five of its 
seven water basins face a real water shortage problem. However, good development practices and water cooperation at national and regional level can help in balancing water needs and water supplies. The improvement of drinking water systems can help in reducing domestic water losses as it reached more than $50 \%$ in some cities. The results showed that reusing all domestic and Industrial wastewater might increase reclaimed water by 1000 MCM in 2050. On the other hand, climate change will have a severe effect on the Syrian water resources. It will decrease the surface and groundwater by about 1300 MCM in 2050. However, rainwater harvesting can contribute as a climate change adaptation technique that can save annually about 2000 MCM.

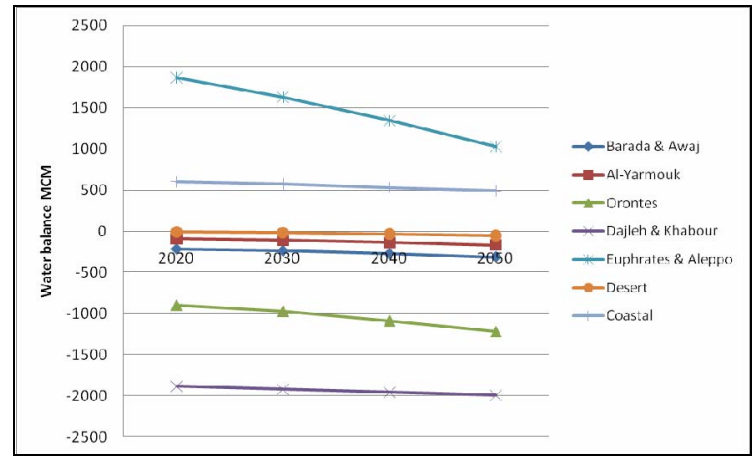

Figure 4. Water balance in the Syrian basins.

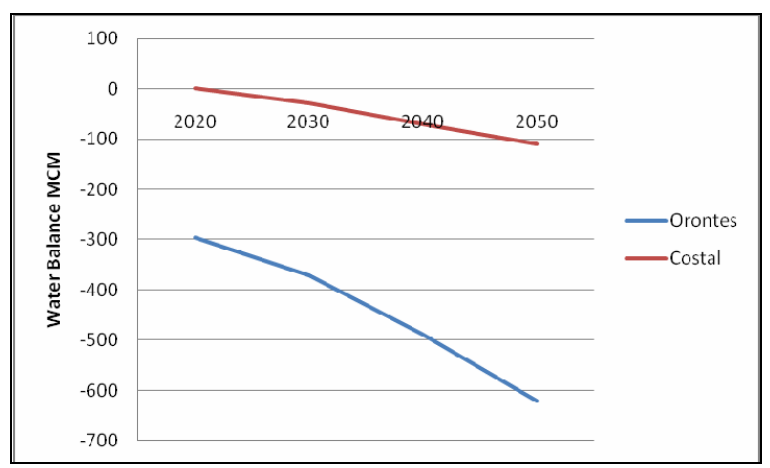

Figure 5. Orontes and costal basins scenario.

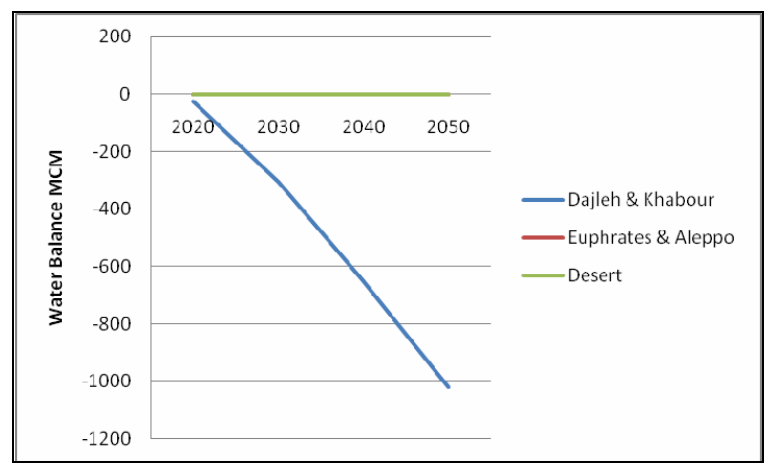

Figure 6. Desert, Dajleh \& Khabour and Euphrates \& Aleppo basins scenario.

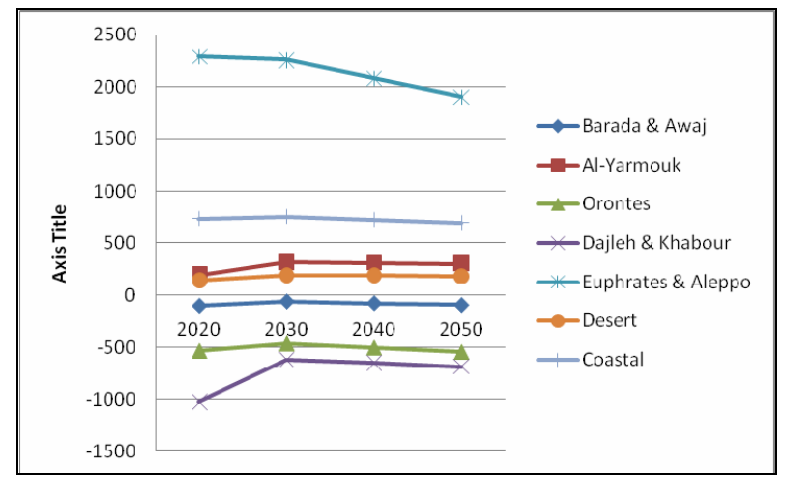

Figure 7. The technical scenario.

Syria is a key country in the Middle East and can possibly serve as an indicator for the area. As seen from the above need its water resources shortage problems could be balanced by reclaimed water and rainwater harvesting. We believe that this is typical for all countries in the Middle East.

\section{Acknowledgements}

Funding from the MECW project at the Center for Middle Eastern Studies, Lund University, is gratefully acknowledged. Valuable cooperation from all stakeholders in Ministry of Irrigation, Ministry of Environment, and other ministries in Syria is also acknowledged.

\section{REFERENCES}

[1] FAO_Food and Agriculture Organization. Aquastat database: Syria Arab Republic, 2011.

http://www.fao.org/nr/water/aquastat/countries/syria/inde X.stm

[2] P. Kerkides, H. Michalopoulou, G. Papaioannou and R. Pollatou, "Water Balance Estimates over Greece," Agriculture Water Management, Vol. 32, No. 1, 1996, pp: 85104. doi:10.1016/S0378-3774(96)01251-6

[3] L. Zhang, N. Potter, K. Hickel, Y. Zhang and Q. Shao, "Water Balance Modeling over Variable Time Scales Based on the Budyko Framework-Model Development and Testing," Journal of Hydrology, Vol. 360, No. 1-4, 2008, pp: 117-131. doi:10.1016/j.jhydrol.2008.07.021

[4] R. C. Owen, "Water Budget and Flow Patterns in an Urban Wetland,” Journal of Hydrology, Vol. 169, No. 1-4, 1995, pp: 171-187. doi:10.1016/0022-1694(94)02638-R

[5] CBS-SYR. Central Bureau of Statistics of Syria, Population and Demographic Indicators, 2011. http://www.cbssyr.org

[6] CBS-SYR, Central Bureau of Statistics of Syria, Number of Private Industrial Projects in Syria, 2011. From http://www.cbssyr.org/Time\%20Series/economic1.htm

[7] GCSAR-General Commission for Scientific Agricultural Research, Country Profile Syria, 2011. http://www.gewamed.net/share/img_country_information 12_read_more...pdf 
[8] Z. Kattan, "Characterization of Surface Water and Groundwater in the Damascus Ghotta Basin: Hydrochemical and Environmental Isotopes Approaches,” Environmental Geology, Vol. 51, No. 2, 2006, pp: 173-201.

[9] MoI-SYR, Ministry of Irrigation in Syria. Agreements with Neighboring Countries, 2011.

http://www.irrigation.gov.sy/index.php?m=118

[10] N. W. Arnell, “Climate Change and Global Water Reso- urces,” Global Environment Change, Vol. 9, Suppl. 1, 1999, pp. S31-S49. doi:10.1016/S0959-3780(99)00017-5

[11] M. J. Trondalen, "Climate Changes, Water Security and Possible Remedies for the Middle East,” Scientific Paper from Potential Conflict to Co-operation Potential (UNESCO PCCP, 2009.

http://www.unwater.org/downloads/181886E.pdf 